\title{
Correction to: Anthropometric and Skin Fold Thickness Measurements of Newborns of Gestational Glucose Intolerant Mothers: Does it Indicate Disproportionate Fetal Growth?
}

\author{
Ramya Shankar $^{1,2,3,4}$ (D) Arulmozhi Ramarajan ${ }^{1} \cdot$ Susheela Rani $^{1,5} \cdot$ V. Seshiah $^{6}$ \\ ๑) Federation of Obstetric \& Gynecological Societies of India 2021
}

\section{Correction to: \\ The Journal of Obstetrics and Gynecology of India (November-December 2020) 70(6):471-478 https://doi.org/10.1007/s13224-020-01340-6}

The article 'Anthropometric and Skin Fold Thickness Measurements of Newborns of Gestational Glucose Intolerant Mothers: Does it Indicate Disproportionate Fetal Growth?', written by Ramya Shankar, Arulmozhi Ramarajan, Susheela Rani and V. Seshiah, was originally published electronically on the publisher's internet portal (currently SpringerLink) on 25 August 2020 with open access.
The original article can be found online at https://doi.org/10.1007/ s13224-020-01340-6.

\section{Ramya Shankar}

drramyashankar@yahoo.co.in

1 Department of Obstetrics and Gynaecology, Church of South India Hospital, No. 2, Hazarat Kambal Posh Road, Bengaluru, Karnataka 560051, India

2 Department of Obstetrics and Gynaecology, MVJ Medical College and Research Hospital, Dandupalya, National Highway 4, 30th km Milestone, Kolathur P.O., Hoskote, Karnataka 562114, India

3 Department of Obstetrics and Gynaecology, St Mary's Hospital, Guddanahalli Road, Lingapura, Malur, Karnataka 563130, India

4 Department of Obstetrics and Gynaecology, St Mary's Hospital, Rayan Circle, Sultan Rd, New Taragypet, Anandapuram, Chamrajpet, Bengaluru, Karnataka 560018, India

5 Department of Obstetrics and Gynaecology, Manjushree Speciality Hospital, \#22/70, St John's Road, Opposite to R.B.A.N.M.S Ground, Bengaluru, Karnataka, India

6 Department of Diabetology, Dr V Seshiah and Dr Balaji Diabetes Care Centre and Research Institution, Chennai, India
With the author(s)' decision to step back from Open Choice, the copyright of the article changed on 30 January 2021 to () Springer Nature B.V. 2021 and the article is forthwith distributed under the terms of copyright. The original article has been corrected.

Publisher's Note Springer Nature remains neutral with regard to jurisdictional claims in published maps and institutional affiliations. 